\begin{tabular}{cc|c}
\hline Tar. Bil. Der. & Journal of Agricultural Sciences \\
& $\begin{array}{c}\text { Dergi web sayfası: } \\
\text { www.agri.ankara.edu.tr/dergi }\end{array}$ & Journal homepage: \\
& www.agri.ankara.edu.tr/journal
\end{tabular}

\title{
Effect of Different Tank Colors on Growth Performance of Rainbow Trout Juvenile (Oncorhynchus mykiss Walbaum, 1792)
}

\author{
Mustafa ÜSTÜNDAĞ $\breve{a}^{\mathrm{a}}$, Ferit RAD ${ }^{\mathrm{a}}$ \\ ${ }^{a}$ Mersin University, Fisheries of Faculty, Department of Aquaculture, Yenişehir, Mersin, TURKEY
}

\section{ARTICLE INFO}

Research Article

DOI: 10.1501/Tarimbil_0000001315

Corresponding Author: Mustafa ÜSTÜNDAĞ, E-mäil: ustundag_mustafa@yahoo.com, Tel: +90 (543) 2650079

Received: 09 February 2014, Received in Revised Form: 09 May 2014, Accepted: 06 June 2014

\begin{abstract}
Effects of four different fiberglass tank colors i.e. beige, grey, dark green and light green on growth performance of rainbow trout (Oncorhynchus mykiss) juveniles $(4.88 \pm 0.71 \mathrm{~g})$ were investigated in this study. The study lasted for 60 days and was conducted under actual culture conditions in a commercial trout farm using spring water with an average temperature of $14.8^{\circ} \mathrm{C}$. Growth performance of fish was evaluated in light of criteria such as mean final weight, specific growth rate (SGR), feed conversion ratio (FCR), energetic growth efficiency (EG), condition factor (K) and survival rate (SR). Mean final weight of fish in beige colored tanks reached $76.26 \pm 10.52 \mathrm{~g}$ while mean final weights of fish in grey, dark and light green tanks were measured as $64.95 \pm 6.94,69.44 \pm 8.81$ and $68.87 \pm 6.42 \mathrm{~g}$, respectively. The differences between mean final weight of fish in 4 experimental groups were found to be statistically significant $(\mathrm{P}<0.05)$. However, no significant differences were found in terms of growth performance criteria among 4 experimental groups $(\mathrm{P}>0.05)$. Highest live weight gain $(71.38 \mathrm{~g})$, SGR $\left(4.58 \%\right.$ day $\left.^{-1}\right)$, EG (45.25\%) and condition factor (1.14) as well as lowest FCR (0.90) were recorded in beige colored tanks. The poorest values of growth performance criteria were observed in fish kept in grey tanks, while fish in dark and light green tanks showed similar performances. Survival rates in experimental groups were similar and varied between $98.25 \%$ and $99.57 \%$. In conclusion it can be specified that under culture condition employed in this study and especially under low light intensities beige colored tanks are more suitable for rearing of rainbow trout fry.
\end{abstract}

Keywords: Rainbow trout; Oncorhynchus mykiss (Wallbaum); Tank color; Growth performance

\section{Farklı Tank Renklerinin Gökkuşağı Alabalığı (Oncorhynchus mykiss Walbaum, 1792) Yavrularının Büyüme Performansı Üzerine Etkisi}

\section{ESER BILGISİ}

Araştırma Makalesi

Sorumlu Yazar: Mustafa ÜSTÜNDAĞ, E-posta: ustundag_mustafa@yahoo.com, Tel: +90 (543) 2650079

Geliş Tarihi:09 Şubat 2014, Düzeltmelerin Gelişi: 09 Mayıs 2014, Kabul: 06 Haziran 2014

\section{ÖZET}

Bu çalışmada açık yeşil, bej, gri ve koyu yeşil olmak üzere 4 farklı cam takviyeli plastik (CTP) tank renginin, ortalama ağırlıkları $4.88 \pm 0.71 \mathrm{~g}$ olan gökkuşağı alabalığı (Oncorhynchus mykiss) yavrularının büyüme performansı üzerindeki etkileri araştırılmıştır. Çalışma 60 gün süre ile fiili yetiştiricilik koşulları altında ve ortalama sıcaklığı $14.8{ }^{\circ} \mathrm{C}$ olan 
kaynak suyu kullanılarak ticari bir alabalık işletmesinde yürütülmüştür. Balıklarda büyüme performansı, ulaşılan son canlı ağırlık, spesifik büyüme oranı (SGR), yem dönüşüm oranı (FCR), enerjitik büyüme etkinliği (EG), kondisyon faktörü $(\mathrm{K})$ ve yaşama oranı (SR) gibi ölçütler değerlendirilmiştir. Çalışma sonunda, bej renkli tanklarda tutulan balıklar ortalama $76.26 \pm 10.52 \mathrm{~g}$ ağırlığa ulaşırken bu değer açık yeşil, gri ve koyu yeşil tanklarda sırasıyla $68.87 \pm 6.42,64.95$ \pm 6.94 ve $69.44 \pm 8.81 \mathrm{~g}$ olarak tespit edilmiştir. Grupların son vücut ağırlığı ortalamaları arasındaki fark istatistiksel olarak önemli bulunmuştur $(\mathrm{P}<0.05)$. Ancak büyüme performansı ölçütleri bakımından deneme grupları arasındaki fark istatistiksel olarak önemli bulunmamakla beraber $(\mathrm{P}>0.05)$ en yüksek canlı ağırlık artışı (71.38 g), SGR (4.58 \% Gün $\left.{ }^{-1}\right)$, TGC (2.87), FCR (0.90) ve EG (\% 45.25) değeri ile kondisyon faktörü (1.14) bej renkli tanklarda tutulan balıklarda saptanmıştır. Bu ölçütler açısından en düşük büyüme performansı ise gri renkli tanklarda gözlenmiştir. Açık ve koyu yeşil tanklardaki balıkların büyüme performansı birbirine yakın bulunmuştur. Deneme sonunda gruplarda saptanan yaşama oranları birbirine yakın olup \% 98.29 ile \% 99.57 arasında değişim göstermiştir. Sonuç olarak bu çalışmanın yürütüldüğü koşullarda ve özellikle düşük 1şık şiddeti altında bej renkli tankların gökkuşağı alabalığı yavrularının yetiştiriciliği için daha uygundur.

Anahtar Kelimeler: Gökkuşağı alabalığı; Oncorhynchus mykiss (Wallbaum); Tank rengi; Büyüme performans1

(C) Ankara Üniversitesi Ziraat Fakültesi

\section{Introduction}

Rearing conditions that differ from environmental requirements of farmed fish species may negatively affect feeding activity, health, welfare and growth especially when culture conditions are stressful (Strand et al 2007). Therefore, design and setup of optimal species-specific culture conditions are of prime importance for successful aquaculture operations.

Color vision is reported to be an important feature for fish living in bright environments enabling them to discriminate details in the ambient surrounding (Luchiari \& Pirhonen 2008). It is well documented that ambient color (e.g. tank color) is one of the environmental factors that can influence growth performance, survival and stress response of fish under culture conditions (Browman \& Marcotte 1987; Karakatsouli et al 2007a; Luchiari \& Pirhonen 2008; J1rsa et al 2009; Luchiari et al 2009; El-Sayed \& El-Ghobashy 2011; Banan et al 2011). According to Papoutsoglou et al (2005) this may be due to direct effect of ambient (tank) color on fish neural/ hormonal processes, behavior and feeding success or can be related to their combined effects.

In visual feeders, feeding success of fish depends on the contrast between the feed and background color. Maximizing the contrast between the feed and the background would facilitate feed detection by fish and thereby improve feeding success under culture conditions (Browman \& Marcotte 1987; Downing \& Litvak 1999; Tamazouzt et al 2000; Jentoft et al 2006; Strand et al 2007; Luchiari \& Pirhonen 2008; McLean et al 2008; Monk et al 2008; Jirsa et al 2009; El-Sayed \& El-Ghobashy 2011; Banan et al 2011). Improved visual detection of feed item is associated with a number of factors including light intensity and background color of rearing units e.g. tanks (McLean et al 2008; Jirsa et al 2009; El-Sayed \& El-Ghobashy 2011). Therefore; choice of proper background color in rearing system would improve growth and survival rates in farmed fish through promoting feed visibility and facilitating feeding success. On the other hand; improper background color may become a source of externally induced stress in fish affecting their behavior, swimming activity and metabolic rates (Suzuki et al 1995; Papoutsoglou et al 2000; Gilchriest et al 2001; Karakatsouli et al 2007a; Strand et al 2007; Luchiari \& Pirhonen 2008; McLean et al 2008; Barcellos et al 2009; El-Sayed \& El-Ghobashy 2011). Both behavioral and physiological stress responses are energy-consuming process that can increase energy expenditure of cultured fish in response to adverse culture conditions and could lead to reduced growth rates and poor performance (Rotlant et al 2003; Strand et al 2007; El-Sayed \& El-Ghobashy 2011).

With the increasing use of fiberglass tanks in aquaculture operations for many aquatic species worldwide, selection of optimal species-specific tank color which would improve fish growth and welfare is becoming more crucial. Fiberglass tanks 
of different colors are commercially available and are widely used in rainbow trout (Oncorhynchus mykiss) hatcheries for fry/juvenile production in many countries. For instance, in Turkey a major rainbow trout producing country in Europe, light and dark green and beige tanks are commonly used in rainbow trout hatcheries. However; the preference or selection criteria for these colors by tank manufacturers and fish farmers remain to be obscure. Studies on effects of ambient/background color on growth performance of rainbow trout fry and juveniles which shed light on selection of optimal tank color is scarce. Studies investigating the effects of ambient/tank colors on growth performance of rainbow trout juveniles are limited to experiments under laboratory conditions by Papoutsoglu et al (2005) and Luchiari \& Pirhonen (2008), using white, blue, green, yellow, red and black plastic tanks or aquaria.

The aim of this study was to contribute to tank color selection for on-growing of rainbow trout juveniles by comparing commercially used standardized color pigments. To this end growth performances of rainbow trout juveniles reared in fiberglass tanks made of four different definable/ standardized (Classic RAL System) colors pigments (beige, light green, dark green and grey) were compared in a commercial farm under actual culture conditions e.g. high stocking densities/water renewal, natural photoperiod, tank dimensions/ volumes and feeding regimes.

\section{Material and Methods}

\subsection{Material}

This experiment was conducted in on-growing unit (out-door tanks shaded with black greenhouse mesh) of a commercial trout farm $\left(39^{\circ} 50^{\prime} ; 2^{\circ} 58^{\prime}\right)$ located in Bilecik Province, Turkey. Five thousand six hundred (5600) rainbow trout juveniles with a mean initial weight of 4.86-4.88 $\mathrm{g}$ were used in the experiment. All juveniles were obtained from all-female imported eggs, hatched and weaned to juvenile stage in the same farm.

Experimental tank set-up was composed of eight 2 -tier tanks of $4.0 \times 1.0 \times 0.5 \mathrm{~m}$ in size, commonly used by commercial trout farms in Turkey. Experimental tanks were manufactured by a private fiberglass tank manufacturer using Classic RAL System standardized color pigments. Three commonly preferred color pigments by commercial farms i.e. beige (Oyster white-RAL 1013), light green (Pale green-RAL 6021), dark green (Chrome green-RAL 6015) and one alternative color pigment resembling natural habitat of Salmonids namely grey (Traffic grey- RAL7042) were used in manufacturing of eight (two for each 4 colors) experimental tanks. Tanks were supplied with water flow-through system using spring water. Water quality parameters were as follows: temperature, 14.8 ${ }^{\circ} \mathrm{C}$; $\mathrm{pH}, 7.75$; dissolved oxygen, $8.99 \mathrm{mg} \mathrm{L}^{-1}$; nitrate, $3.68 \mathrm{mg} \mathrm{L}^{-1}$; chloride, $2.69 \mathrm{mg} \mathrm{L}^{-1}$ and total hardness, $199 \mathrm{mg} \mathrm{L}^{-1} \mathrm{CaCO}_{3}$.

Throughout the experiment commercial rainbow trout feed of varying size (800-1000 micro granule-1.5-3.0 mm sinking pellets) was used. Crude protein, crude fat and digestible energy content of feeds were $55-45 \%, 15-20 \%$ and $4523-4389 \mathrm{kcal}$ $\mathrm{kg}^{-1}$, respectively.

\subsection{Methods}

This experiment was run from $8^{\text {th }}$ July to $5^{\text {th }}$ September 2011 (60 days) under actual farming conditions with minor modifications in routine farming practices to ensure the reliability of statistical assessments. To this end unlike commercial farming practices, no periodic size grading/selection and stocking adjustments was carried and initial fish material and fish number/tank was kept unchanged (except mortalities) throughout the experiment.

Five thousand six hundred rainbow trout juveniles were stocked to beige light green, dark green and grey experimental tanks in duplicates (700 juveniles tank $\mathrm{k}^{-1}$ ). Initial mean weight of fish in light green, dark green, grey and beige experimental groups was arranged as $4.89 \pm 0.69,4.87 \pm 0.75$, and $4.87 \pm 0.71$ and $4.89 \pm 0.71 \mathrm{~g}$, respectively. Differences between mean initial weights of fish in four experimental groups were thus statistically insignificant $(\mathrm{P}>0.05)$. Water flow rate per tank was adjusted according to biomass and being $0.8 \mathrm{~L} \mathrm{sec}^{-1}$ (day 1-29), $1.5 \mathrm{~L} \mathrm{sec}^{-1}$ (day 30-45) and $2.5 \mathrm{~L} \mathrm{sec}^{-1}$ (day 46-60) in all experimental tanks. All tanks were siphoned every two days. Dissolved oxygen and 
water temperature was monitored every two days. Mortalities were monitored everyday and dead fish were recorded.

Shaded with black greenhouse mesh, experiment tanks were subject to natural photoperiod $\left(39^{\circ} 50^{\prime}\right.$; $29^{\circ} 58^{\prime}$ Bozüyük/Bilecik). Light intensity (lux) was measured from tank water surface at varying hours of the day (10:00, 14:00 and 17:00 hour) using a digital lux meter. Lowest, highest and mean light intensities were measured as 8, 27 and 39 lux, respectively.

Based on routine practices of the farm, fish were fed by hand to apparent satiation 5 times per day $(08: 30 ; 10: 30 ; 13: 30 ; 16: 00$ and $18: 00)$ for the first 15 days of the experiment. In the remaining 45 days fish were fed 4 times a day $(08: 00 ; 11: 00 ; 14: 00$ and 18:00). Certain amount of feed was weighed and slowly distributed over water surface until apparent satiation was considered attained (slowdown of swimming and feeding activity) in each tank. Due to scale of experimental setup including tank volume/shape and amount of feed handled daily it was not possible to collect uneaten feed from tanks to calculate feed consumption. The total amount of feed delivered until the point of apparent satiation at each feeding interval was therefore, considered as daily feed consumption in each tank. Since no size grading and selection was practiced during starting from $10^{\text {th }}$ day of the experiment tanks contained fish of different size classes. Daily rations were therefore prepared by mixing pellets of different size according to feed manufacturers' recommendation on appropriate fish-pellet size (Table 1).

Table 1- Pellet feed mixture used during the experiment

Çizelge 1- Denemede kullanılan pelet yem karışımı

\begin{tabular}{ll}
\hline Day & Particle size of feed \\
\hline $1-10$ & $800-1000$ micro granule \\
$11-15$ & $800-1000$ micro granule-1 $\mathrm{mm}$ micro pellet \\
$16-22$ & $\begin{array}{l}800-1000 \text { micro granule-1 } \mathrm{mm} \text { and } 1.5 \mathrm{~mm} \\
\text { micro pellet }\end{array}$ \\
$23-30$ & $1 \mathrm{~mm}$ and $1.5 \mathrm{~mm}$ micro pellet \\
$31-45$ & $1 \mathrm{~mm}, 1.5 \mathrm{~mm}$ micro- 2 mm micro sinking pellets \\
$46-52$ & $\begin{array}{l}1.5 \mathrm{~mm} \text { micro- } 2 \mathrm{~mm} \text { micro sinking and } 3 \mathrm{~mm} \\
\text { sinking pellets }\end{array}$ \\
$53-60$ & $2 \mathrm{~mm}$ micro sinking and $3 \mathrm{~mm}$ sinking pellets \\
\hline
\end{tabular}

Fish growth was monitored every two weeks (day $15^{\text {th }}, 30^{\text {th }}, 45^{\text {th }}$ and $\left.60^{\text {th }}\right)$ by weight $(\mathrm{g})$ and total length (cm) measurements on 100 randomly selected fish samples from each tank in four experimental groups (200 fish/experimental group). Growth performance of fish in four experimental groups were compared in terms of specific growth rate (SGR), feed conversion ratio (FCR), energetic growth efficiency (EG), survival rate (SR), and condition factor $(\mathrm{K})$ as following (Han et al 2005; Larsson \& Berglund 2005; Bekcan \& Atar 2012; Banan et al 2011):

$S G R\left(\% d a y^{-1}\right)=\frac{(\ln \mathrm{WF}-\ln \mathrm{WI})}{\mathrm{t}} \times 100$

Where; WF, mean final body weight (g); WI, mean initial body weight $(\mathrm{g})$; $\mathrm{t}$, duration of the experiment (days)

$$
\begin{aligned}
& F C R=\frac{\text { Weight of feed offered }(\mathrm{kg}, \text { dry weight })}{\text { Mean biomass gain }(\mathrm{kg}, \text { wet weight })} \\
& E G(\%)=\frac{\mathrm{J} \times(\mathrm{WF}-\mathrm{WI})}{\mathrm{P} \times \mathrm{V}}
\end{aligned}
$$

Where; J, conversion factor of mass to energy for Salmonidae $\left(7.5 \mathrm{~kg}^{-1}\right)$; P, weight of feed consumed (g); V, mean digestible energy content of feeds used throughout the experiment $\left(\mathrm{kJ} \mathrm{g}^{-1}\right.$, based on feed manufacturers' declaration)

$$
S R(\%)=\frac{\mathrm{NF}}{\mathrm{NI}} \times 100
$$

Where; NF, final number of fish; NI, Initial number of fish

$$
K=\frac{\text { Fish weight }(\mathrm{g})}{\text { Fish length }\left(\mathrm{cm}^{3}\right)} \times 100
$$

Estimated SGR, FCR, TGC and EG values for four experimental groups are presented as means of duplicated tanks for 4 experimental period each consisting of 15 days. Condition factor $(\mathrm{K})$ was calculated for each fish individually at the end of the experiment and then converted to mean values. In terms of growth performance parameters statistical significance between experimental groups (tank colors) was evaluated by one-way analysis of variance (ANOVA) and Post Hoc Tests (Tukey HSD) using SPSS 11.5 and MedCalc ${ }^{\circledR}$ V11.0.1 statistical tools. 


\section{Results and Discussion}

Growth patterns of fish in beige, dark green, grey and light green colored tanks are presented in Table 2. Starting from day $30^{\text {th }}$, fish reared in beige colored tanks showed higher weight gains than fish in other groups throughout the 60 day experiment. Fish in beige tanks ended up with a mean final body weight of $76.26 \pm 10.52 \mathrm{~g}$ which was significantly higher than those kept in dark green, grey and light green colored tanks $(\mathrm{P}<0.05)$. The mean final weight of fish reared in dark and light green tanks were measured as $69.44 \pm 8.81$ and $68.87 \pm 6.42 \mathrm{~g}$ respectively but were not significantly different from each other $(\mathrm{P}>0.05)$. The lowest mean final body weight $(64.95 \pm 6.94 \mathrm{~g})$ was observed in fish kept in grey colored tanks.
Apparent feed consumption of fish in four experimental groups is presented in Table 3. At the end of the experiment highest feed consumption was observed in beige colored tanks while fish in grey tanks had the lowest feed compared to other tank colors.

Growth performance parameters including specific growth rate (SGR), condition factor (K), feed conversion ratio (FCR), energetic growth efficiency (EG) and survival rate (SR) for beige, dark green, grey and light green colored tanks are presented in Table 4.

Statistical analysis did not reveal any significant differences in terms of growth performance parameters between experimental groups $(\mathrm{P}>0.05)$. However, fish in beige colored tanks had a relatively

Table 2- Growth patterns (live weight) of rainbow trout juveniles in different colored tanks Çizelge 2- Farklı renkteki tanklarda gökkuşă̆l alabalığı yavrularının büyüme (canlı ağırlık) düzeni

\begin{tabular}{lccccc}
\hline \multicolumn{1}{c}{ Experimental } & \multicolumn{5}{c}{ Body weight $^{*}(g)$} \\
\cline { 2 - 5 } \multicolumn{1}{c}{ group } & Initial & Day 15 & Day 30 & Day 45 & Final \\
\hline Beige tanks & $4.89 \pm 0.71^{\mathrm{a}}$ & $14.76 \pm 1.20^{\mathrm{b}}$ & $28.73 \pm 1.97^{\mathrm{b}}$ & $49.29 \pm 2.54^{\mathrm{b}}$ & $76.26 \pm 10.52^{\mathrm{b}}$ \\
Dark green tanks & $4.87 \pm 0.75^{\mathrm{a}}$ & $14.15 \pm 1.32^{\mathrm{a}}$ & $27.54 \pm 1.88^{\mathrm{ac}}$ & $45.25 \pm 2.04^{\mathrm{a}}$ & $69.44 \pm 8.81^{\mathrm{a}}$ \\
Grey tanks & $4.87 \pm 0.71^{\mathrm{a}}$ & $14.48 \pm 1.00^{\mathrm{bc}}$ & $27.70 \pm 1.63^{\mathrm{c}}$ & $43.76 \pm 2.28^{\mathrm{c}}$ & $64.95 \pm 6.94^{\mathrm{c}}$ \\
Light green tanks & $4.89 \pm 0.69^{\mathrm{a}}$ & $14.30 \pm 0.99^{\mathrm{ac}}$ & $27.25 \pm 1.31^{\mathrm{a}}$ & $44.83 \pm 2.83^{\mathrm{a}}$ & $68.87 \pm 6.42^{\mathrm{a}}$ \\
\hline
\end{tabular}

", means in the same column denoted by different superscripts indicate significant statistical difference between tank colors $(\mathrm{P}<0.05)$

\section{Table 3- Feed consumption of rainbow trout juveniles in different colored tanks}

Çizelge 3- Farklı renkteki tanklarda gökkuşă̆ alabalığı yavrularının yem tüketimi

\begin{tabular}{lcccc}
\hline \multirow{2}{*}{ Period } & \multicolumn{4}{c}{ Experimental group /Feed consumption $(g)$} \\
\cline { 2 - 5 } & Light green & Beige & Grey & Dark green \\
\hline First 15 days & 13710 & 12668 & 14585 & 13561 \\
Second 15 days & 16905 & 17214 & 16990 & 17141 \\
Third 15 days & 22963 & 25468 & 20563 & 22538 \\
Forth 15 days & 31865 & 34788 & 28917 & 32134 \\
Total (60 days) & 85047 & 90138 & 81055 & 85374 \\
\hline
\end{tabular}

Table 4- Growth performance of rainbow trout juveniles in different colored tanks

Çizelge 4- Farklı renkteki tanklarda gökkuşă̆ı alabalı̆̆ yavrularının büyüme performansı

\begin{tabular}{lcccc}
\hline Growth performance & \multicolumn{4}{c}{ Experimental groups ${ }^{*}$} \\
\cline { 2 - 5 } \multicolumn{1}{c}{ parameters } & Beige tanks & Dark green tanks & Grey tanks & Light green tanks \\
\hline SGR $^{1}\left(\%\right.$ day $\left.^{-1}\right)$ & $4.58 \pm 1.83^{\mathrm{a}}$ & $4.43 \pm 1.78^{\mathrm{a}}$ & $4.32 \pm 1.95^{\mathrm{a}}$ & $4.41 \pm 1.79^{\mathrm{a}}$ \\
K & $1.14 \pm 0.14^{\mathrm{a}}$ & $1.03 \pm 0.16^{\mathrm{a}}$ & $0.97 \pm 0.17^{\mathrm{a}}$ & $1.04 \pm 0.17^{\mathrm{a}}$ \\
FCR & $0.90 \pm 0.02^{\mathrm{a}}$ & $0.95 \pm 0.06^{\mathrm{a}}$ & $0.97 \pm 0.07^{\mathrm{a}}$ & $0.96 \pm 0.06^{\mathrm{a}}$ \\
EG (\%) & $45.25 \pm 1.19^{\mathrm{a}}$ & $43.00 \pm 3.00^{\mathrm{a}}$ & $42.00 \pm 3.25^{\mathrm{a}}$ & $42.75 \pm 2.50^{\mathrm{a}}$ \\
SR (\%) & 99.50 & 99.29 & 98.29 & 99.57 \\
\hline
\end{tabular}

*, means in the same line denoted by the same superscripts indicate insignificant statistical difference between tank colors $(\mathrm{P}>0.05)$ 
better growth performance in terms of SGR, $\mathrm{FCR}, \mathrm{EG}$ and $\mathrm{K}$ values compared to other three experimental tank colors. On the other hand growth performance of fish reared in grey colored in terms of SGR, FCR, EG and $\mathrm{K}$ values was lower than other three experimental groups. Fish in dark and light green tanks had more or less similar growth performances.

Studies on effect of light and/or tank color on growth performance and other physiological aspects of fish species and especially rainbow trout under culture conditions are scant. This restricts broad and in-depth discussion of results in light of findings from other relevant studies. Studies on effects of light or tank color on growth performance of rainbow trout are limited to those carried out by Papoutsoglou et al (2005), Karakatsouli et al (2007a), Karakatsouli et al (2008) and Luchiari \& Pirhonen (2008). Of these only Papoutsoglou et al (2005) and Luchiari \& Pirhonen (2008) have investigated the effect of environmental color (tank or aquaria) on growth of rainbow trout juveniles. Accordingly, Papoutsoglou et al (2005) have observed reduced fish growth in black tanks, but no significant differences between fish reared in light blue or white tanks. On the other hand Luchiari \& Pirhonen (2008) have investigated growth of rainbow trout juvenile under white, blue, green, yellow and red environment and have suggested green as the best environmental color for rearing of juvenile rainbow trout.

In our study mean final weight of fish reared in different tank colors were significantly different $(\mathrm{P}<0.05)$ and highest mean final body weight $(76.26 \pm 10.52 \mathrm{~g})$ was measured in fish reared in beige colored tanks. Though not statistically significant fish reared in beige tank had also a better growth performance in terms of SGR, FCR, EG and $\mathrm{K}$ values compared to other three experimental tank colors. In terms of fish growth performance dark green, light green and grey colored tanks followed beige tanks, respectively.

When comparing our results with above mentioned studies, one should bear in mind that even on the same species reaction of fish to tank color may vary according to life stage, stocking density, water temperature and quality, feeding pattern, photoperiod and light intensity (Papoutsoglou et al 2000; Papoutsoglou et al 2005). As mentioned earlier the aim of this study was to contribute to tank color selection for on-growing of rainbow trout juveniles by comparing four different definable/ standardized (Classic RAL System) commercially used tank colors pigments under actual culture conditions. Therefore; experimental setup and conditions in this study e.g. stocking densities, photoperiod, light intensity, tank dimensions/ volumes and feeding regimes were different from those of Papoutsoglou et al (2005) and Luchiari \& Pirhonen (2008) which have been conducted under laboratory conditions. For instance Papoutsoglou et al (2005) have investigated the influence of black, light blue and white cylindrical tanks $(90 \mathrm{~L})$ on growth performance of rainbow trout juveniles under 12L:12D photoperiod regime and 250 lux light intensity. In their growth trial Luchiari \& Pirhonen (2008) have used aquaria (15 L) covered from the sides with blue, red, yellow, green or white paper, setting illumination at 60 lux and applying a photoperiod of 24L:0D.

Combined effect and interaction of tank color and light intensity could be an explanation for relatively better growth performance of rainbow trout juveniles kept in beige colored tanks in this study. Average ambient light intensity in this study was 39 lux. According to many studies under low light intensities which is the also the case for this study, light background colors (e.g. white or yellow) provide a better feed-background contrast and thus improve feed detection by fish. This improved detection of feed in turn enhances feeding success which leads to higher somatic growth in fish (Papoutsoglou et al 2005; Kararkatsouli et al 2007b; Strand et al 2007; McLean et al 2008; El-Sayed \& El-Chbashy 2011). Higher feed intake in fish could also be associated with several neuro-hormonal mechanisms including melanin-concentrating hormone $(\mathrm{MCH})$ which is related to skin lightening on a white background and is believed to stimulate food intake and somatic growth in fish (Yamanome 
et al 2005; Kararkatsouli et al 2007b). Indeed feed consumption of fish reared in beige tanks (90 $138 \mathrm{~g}$ ) was relatively higher than those kept in dark green, light green and grey tanks. Higher feed consumption in beige colored tanks can be an explanation for higher mean final weight and thus better SGR.

Many studies also underline that tank color and ambient light intensity can also be a source of stress for fish influencing their behavior and metabolic activities (Papoutsoglu et al 2000; Strand et al 2007; El-Sayed \& El-Ghobashy 2011). Both behavioral and physiological stress responses are energy draining process which may increase energy expenditure of fish and thus reduce somatic growth and feed efficiency (Papoutsoglu et al 2000; Rotllant et al 2003; Strand et al 2007; McLean et al 2008). Lower mean final weights and poorer FCR and EG values in fish reared in grey colored tanks may be associated with stress physiology. Accordingly it can be assumed that fish in grey tanks were under stressful conditions which increased energy expenditure of fish for stress responses and led to lower somatic growth and FCR. Though not statistically significant $(\mathrm{P}>0.05)$ survival rate of fish in grey colored tanks $(98.29 \%)$ was also lower than fish in other three tank colors. This lower survival rate could also be regarded an indication of stressful conditions in grey tanks.

On the other hand higher mean final weights and thus better FCR and EG values in fish kept in beige tanks can be regarded as an indication that beige color provided a more suitable environment for fish than other three experimental colors and specifically grey tank color.

\section{Conclusions}

Finally it can be concluded that under low light intensities beige colored fiberglass tanks may be more suitable for on-growing of rainbow trout juveniles than light green, dark green and grey tanks. However; this assertion cannot be generalized since different culture conditions and specifically combined effect of tank color and light intensity and interaction may lead to different growth patterns and results. To generalize the results obtained, further studies using same tank colors and different light intensities are needed. Further in-depth studies on effect of tank color on stress physiology of rainbow trout juveniles using biological indicators of stress e.g. plasma cortisol are also essential for generalization of results since such indicators were not measured in this study.

\section{Acknowledgements}

Authors would like to thank Kuzey Su Ürünleri for their support to this research which was conducted as a M.Sc. Thesis.

\section{References}

Banan A, Kalbassi M R, Bahmani M \& Sadati M A Y (2011). Effects of colored light and tank color on growth indices and some physiological parameters of juvenile beluga (Huso huso). Journal of Applied Ichthyology 27: 565-570

Barcellos L J G, Kreutz L C, Quevedo M R, Rosa J G S, Kaokoski L, Centenaro L \& Pottker E (2009). Influence of color background and shelter avaibility on jundia (Rhamdia guelen) stress response. Aquaculture 288: $51-56$

Bekcan S \& Atar H H (2012). Effects of live feeds and compounded diet on growth parameters of brown trout fry (Salmo trutta abanticus T. 1954) in the context of habitat restoration. Tartm Bilimleri Dergisi-Journal of Agricultural Sciences 18(2012): 137-145

Browman H İ \& Marcotte B M (1987). Effects of prey color and background color on feeding by Atlantic Salmon Alevins. The Progressive Fish-Culturist 49: 140-143

Downing G \& Litvak M K (1999). The effect of photoperiod, tank colour and light intensity on growth of larval haddock. Aquaculture International 7: 369382

El-Sayed A \& El-Ghobashy A E (2011). Effects of tank color and feed colour on growth an feed utilization of thin lip mullet (Liza ramada) larvae. Aquaculture Research 42: 1163-1169.

Gilchriest B J, Tipping D J, Hake L, Levy A \& Baker B I (2001). Differences in Arginine Vasotocin Gene Transcripts and Cortisol Secretion in Trout with High or Low Endogenous Melanin-Concentrating 
Hormone Secretion. Journal of Neuroendocrinology 13: 407 - 411

Han D, Xie S, Lei W, Zhu X \& Yunxia Yang (2005). Effect of light intensity on growth, survival and skin color of juvenile Chinese longsnout catfish (Leiocassis longirostris Günther). Aquaculture 248: 299-306

Jentoft S, Øxnevad S, Aastveit A H \& Andersen Ø (2006). Effects of tank wall color and up-welling water flow on growth and survival of Eurasian Perch Larvae (Perca fluviatilis). Journal of the World Aquaculture 37(3): 313-317

Jirsa D, Drawbridge M \& Stuart K (2009). The effects of tank color and light intensity on growth, survival, and stress tolerance of White seabass, Atractoscion nobilis, larvae. Journal of the World Aquaculture 40(5): 702-709

Karakatsouli N, Papoutsoglou S E, Pizzonia G, Tsatsos G, Tsopelakos A, Chadio S, Kalogiannis D, Dalla C, Polissidis A \& Papadopoulou-Daifoti Z (2007a). Effects of light spectrum on growth and physiological status of gilthead sewabream Sparus aurata and rainbow trout Onchorhynchus mykiss reared under recirculating system conditions. Aquaculture Engineering 36: 302-309

Karakatsouli N, Papoutsoglou S E \& Manolessos G (2007b). Combined effects of rearing density and tank color on the growth and welfare of juvenile white Sea bream Diplodus sargus L. in a recirculating water system. Aquaculture Research 38: 1152-1160

Karakatsouli N, Papoutsoglou S E, Panopoulos G, Papoutsoglou E S, Chadio S \& Kalogiannis D (2008). Effects of light spectrum on growth and stress response of rainbow trout Oncorhynchus mykiss reared under recirculating system conditions. Aquaculture Engineering 38: 36-42

Larsson S \& Berglund I (2005). The effect of temperature on the energetic growth efficiency of Arctic charr (Salvelinus alpinus L.) from four Swedish populations. Journal of Thermal Biology 30: 29-36

Luchiari A C, Morais Freire F A, Pirhonen J \& Koskela J (2009). Longer wavelengths of light improve the growth, intake and feed efficiency of individually reared juvenile pikeperch Sander lucioperca (L). Aquaculture Research 40: 880-886
Luchiari A C \& Pirhonen J (2008). Effects of ambient colour on colour preference and growth of juvenile rainbow trout Oncorhynchus mykiss (Walbaum). Journal of Fish Biology 72: 1504-1514

McLean E, Cotter P, Thain C \& King N (2008). Tank color impacts performance of cultured fish. Ribarstvo 66(2): 43-54

Monk J, Puvanendran V \& Brown J A (2008). Does different tank bottom colour affect the growth, survival and foraging behaviour of Atlantic cod (Gadus morhua) larvae? Aquaculture 257: 287-293

Papoutsoglou S E, Mylonakis G, Miliou H, Karakatsouli N P \& Chadio S (2000). Effects of background color on growth performances and physiological responses of scaled carp (Cyprinus carpio L.) reared in a closed circulated system. Aquacultural Engineering 22: 309-318

Papoutsoglou S E, Karakatsouli N \& Chiras G (2005). Dietary 1-tryptophan and tank colour effects on growth performance of rainbow trout (Oncorhynchus mykiss) juveniles reared in a recirculating water system. Aquacultural Engineering 32: 277-284

Rotllant J, Tort L, Monteroc D, Pavlidis M, Martinez M, Bonga S E W \& Balme P H M (2003). Background colour influence on the stress response in cultured red porgy Pagrus pagrus. Aquaculture 223: 129-139

Strand Å, Alanärä A, Staffan F \& Magnhagen C (2007). Effects of tank colour and light intensity on feed intake, growth rate and energy expenditure of juvenile Eurasian perch, (Perca fluviatilis L.). Aquaculture 272: $312-318$

Suzuki M, Narnaware Y K, Baker B I \& Levy A (1995). Influence of Environmental Colour and Diurnal Phase on $\mathrm{MCH}$ Gene Expression in the Trout. Journal of Neuroendocrinology 7: 319- 328

Tamazouzt L, Chatain B \& Fontaine P (2000). Tank wall colour and light level affect growth and survival of Eurasian perch larvae (Perca fluviÍiatilis L.). Aquaculture 182: 85-90

Yamanome T, Amano M \& Takahashi A (2005). White background reduces the occurrence of staining, activates melanin-concentrating hormone and promotes somatic growth in barfin flounder. Aquaculture 244: 323- 329 